\title{
The impact of SME access to finance and performance on exporting behaviour at firm level: A case of furniture manufacturing SMEs in Zimbabwe
}

\begin{tabular}{|c|c|}
\hline \multicolumn{2}{|c|}{$\begin{array}{l}\text { Authors: } \\
\text { Kin Sibanda }{ }^{1} \\
\text { Progress Hove-Sibanda }{ }^{2} \\
\text { Herring Shava }{ }^{3} \text { (D) }\end{array}$} \\
\hline \multicolumn{2}{|c|}{$\begin{array}{l}\text { Affiliations: } \\
{ }^{1} \text { Department of Economics, } \\
\text { University of Fort Hare, } \\
\text { South Africa }\end{array}$} \\
\hline \multicolumn{2}{|c|}{$\begin{array}{l}{ }^{2} \text { Department of Transport } \\
\text { Economics and Logistics, } \\
\text { North-West University, } \\
\text { South Africa }\end{array}$} \\
\hline \multicolumn{2}{|c|}{$\begin{array}{l}{ }^{3} \text { Department of Business } \\
\text { Management, University } \\
\text { of Fort Hare, South Africa }\end{array}$} \\
\hline \multicolumn{2}{|c|}{$\begin{array}{l}\text { Corresponding author: } \\
\text { Herring Shava, } \\
\text { hshava@ufh.ac.za }\end{array}$} \\
\hline \multicolumn{2}{|c|}{$\begin{array}{l}\text { Dates: } \\
\text { Received: } 12 \text { Sept. } 2017 \\
\text { Accepted: } 26 \text { Mar. } 2018 \\
\text { Published: } 28 \text { June } 2018\end{array}$} \\
\hline \multicolumn{2}{|c|}{$\begin{array}{l}\text { How to cite this article: } \\
\text { Sibanda, K., Hove-Sibanda, P. } \\
\text { \& Shava, H., 2018, 'The } \\
\text { impact of SME access to } \\
\text { finance and performance on } \\
\text { exporting behaviour at firm } \\
\text { level: A case of furniture } \\
\text { manufacturing SMEs in } \\
\text { Zimbabwe', Acta Commercii } \\
\text { 18(1), a554. https://doi. } \\
\text { org/10.4102/ac.v18i1.554 }\end{array}$} \\
\hline \multicolumn{2}{|c|}{$\begin{array}{l}\text { Copyright: } \\
\text { (C) 2018. The Authors. } \\
\text { Licensee: AOSIS. This wor } \\
\text { is licensed under the } \\
\text { Creative Commons } \\
\text { Attribution License. }\end{array}$} \\
\hline \multicolumn{2}{|l|}{ Read online: } \\
\hline 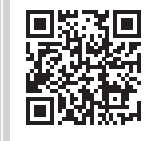 & $\begin{array}{l}\text { Scan this QR } \\
\text { code with your } \\
\text { smart phone or } \\
\text { mobile device } \\
\text { to read online. }\end{array}$ \\
\hline
\end{tabular}

Orientation: Globally, the majority of Small and Medium-sized entities (SMEs) are resource constrained. As a result, not all SMEs are able to fully exploit the benefits associated with international trade as they face challenges when exporting their produce.

Research purpose: This article presents an investigation into the impact of access to finance on firm performance and exporting behaviour of SMEs in Harare, Zimbabwe.

Motivation for the study: The article stems from the observation that although there is a growing importance and contribution of SMEs worldwide, research has shown that only a few of these SMEs are involved in international trade.

Research design, approach and method: A cross-sectional study was employed with quantitative methods being utilised. The collected data were analysed using a structural equation modelling technique, which employed the Smart partial least squares software (version 2.0).

Main findings: The key findings reveal that a significant positive relationship between access to finance and SMEs exporting behaviour does exist. Furthermore, the study's findings challenge the notion that firm performance has a significant impact on exporting behaviour and show a negative impact of access to finance on SME firm performance.

Practical/managerial implications: There is a need to put systems in place in Zimbabwe that that will (1) prioritise the need to have clear routes to market and increase awareness among SME owners, and (2) help SMEs overcome high costs associated with participating in export of goods and services.

Contribution/value-add: The article provides a unique empirical analysis of the relationship that exists between access to finance, firm performance and export behaviour of SME firms in Zimbabwe, and thereby makes a valid contribution to SME literature.

\section{Introduction}

Financing of small- and medium-sized entities (SMEs) has been a subject of debate between policymakers, researchers and other stakeholders globally. The debate is fuelled by the important role that SMEs continue to play in the private sector across the globe and includes employment creation (Ayyagari et al. 2016; Naude \& Chiweshe 2017).

Small- and medium-sized entities constitute a vast section of the private sector in the majority of developed and developing countries (Beck \& Demirguc-Kunt 2006). From a regional perspective, Irene (2017) cited Abor and Quartely (2010) and provided a Southern African perspective stating that SMEs contributed $57 \%$ towards the gross domestic product (GDP) and accounted for $61 \%$ of jobs created in the country. From a global perspective, Stouraitis, Harun and Kyritsis (2017) cited Gerlach-Kristen, O'Connell and O'Toole (2015) indicating that SMEs contributed towards 50\% of the global GDP and $60 \%$ of global employment.

After a review of 50 empirical studies focusing on the job creation of SMEs in developing countries, Deijl, De Kok and Veldhuis-Van Essen (2013) concluded that SMEs created two-thirds and 80\% of all formal jobs in emerging and low-income economies, respectively. The above stated figures are a testimony to the important role that SMEs continue to play across the globe towards economic stability and development.

Milanzi (2012) also acknowledged the importance of SMEs and their contributions towards a nation's total exports. In that regard, Edmunds and Khoury (1986) provided evidence revealing 
the criticality of exports towards SME performance and profitability. Because of the evidence, Edmunds and Khoury (1986) strongly declared that SMEs must be involved in international markets. Exports play a crucial role for SMEs both as an economic activity and as a driver of economic development of a nation (Milanzi 2012). For instance, about one-fifth of manufacturing SMEs enjoy sales revenues ranging from $10 \%$ to $40 \%$ of their total sales revenues from exports (Damoah 2011).

The Confederation of Zimbabwe Industries (CZI 2011) pointed out that since the collapse of the formal economy from early 2000, Zimbabwe has experienced unprecedented growth of SMEs. Sanderson (2014) argued that identifying the importance of the sector was mainly because of the fact that the majority of large firms were downsizing and in the worst scenario, closing shop. Despite the growing importance of SMEs in Zimbabwe and the worldwide acknowledgement of SME contribution to economic activities, few are participating in the buying and selling of goods in global markets (Bhalla et al. 1999; Chingwaru \& Jakata 2015; CZI 2015; Gumede 2000; Kapoor, Mugwara \& Chidawaenzi 1997; Milanzi 2012; Mpofu 1998; Zindiye 2008).

Pinho and Martins (2010) also echoed the same sentiments and pointed out that SMEs that engage in selling and buying of goods at a global stage stand to benefit in numerous ways, although only a few seem to exploit such opportunities. In support of the above argument, Chingwaru (2014) found that $24 \%$ and $31 \%$ of South African and Zimbabwean SMEs were exporting their final produce, respectively.

This trend is more pronounced in emerging economies and often exhibited by SMEs. Milanzi (2012) argued that evidence suggests that a few SMEs are taking part in the selling and buying of goods and services at a global stage, especially SMEs from sub-Saharan Africa. Among those SMEs who buy and sell goods at a global stage, a smaller portion of their output finds its way to the global market (Chingwaru 2014).

The low export involvement of developing country SMEs might be because of their failure to access finance from local and international capital markets (Chipangura \& Kaseke 2012). This relates to the inaccessibility of formal long-term and short-term loans for investing in non-current assets and for working capital purposes so that SMEs could enhance their operations (Ferrando \& Mavrakis 2017; Oricchio et al. 2017).

Karedza and Govender (2017) cited Damoah (2011) who argued that theoretical frameworks regarding SME exporting behaviour and export performance for developed or Western nations are readily available. In contrast, literature on the same subject from African countries is scarce.

It is therefore the goal of this study to contribute to literature through investigating how access to finance impacts the export behaviour of SMEs in Harare, Zimbabwe. The study also investigates whether access to finance has an impact on
SME performance. In addition, the impact of firm performance on SME export behaviour is examined.

The next section reviews literature on the constructs of the study leading to hypotheses formulation. Thereafter, the study further reviews the literature justifying why the study focused on SMEs in Zimbabwe. This is performed by focusing on four aspects. Firstly, the definition of SMEs in the Zimbabwean context; secondly, SMEs' access to finance and exporting behaviour in the Zimbabwean context; thirdly, SMEs' access to finance and performance in the Zimbabwean context, with the last aspect being firm performance and exporting behaviour in the Zimbabwean context. Later sections focus on the research objectives, methodology, results, implications to theory and practice. The last section provides the conclusion of the study.

\section{Literature review}

Economic literature has recently emphasised the strong impact of access to finance on entity decisions to engage in export activities (Chaney 2005; Manova 2006). Chingwaru and Jakata (2015) argued that accessing foreign markets is associated with large additional fixed and sunk costs, related to information gathering on foreign markets, establishing a reliable distribution system, adapting products to foreign tastes and preferences as well as environment. In addition, variable costs in foreign markets are high relative to the domestic market and these include shipping and insurance as well as other trade barriers. Saddening to note is the fact that SMEs continue to struggle to meet these costs because of limited access to finance.

In keeping with the foregoing, Bernard, Stabilito and Yoo (2010) argued that inadequate access to financial services is one of the main constraints facing entities in their bid to enter the export market. Beck and Demirguc-Kunt (2006) also echoed the same sentiments, stating that SMEs are financially more constrained than large firms and are less likely to have access to formal finance (long-term loans).

The global financial crisis of 2007 resulted in the world's biggest recession since the great depression (Carbó-Valverde, Rodríguez-Fernández \& Udell 2016). Contessi and De Nicola (2012) reported that the world's GDP fell by $0.57 \%$ with the advanced economies experiencing a $3.48 \%$ decline, recorded as the largest decline in 50 years. International trade across the world suffered a huge collapse during this period. Contessi and De Nicola stated that the volume of exports fell by a staggering $11.2 \%$ and $7.6 \%$ in advanced and emerging economies, respectively. This unexpected and costly decline in global trade resulted in vast research into the causes and implications of such a decline. The global decline in trade volumes was attributed largely to the credit crunch because it reduced exporters' access to finance.

The global financial crisis affected the financial sector of many countries and Zimbabwe was not spared. Muvingi (2011) reported that Zimbabwe's financial sector has experienced 
a very difficult financial crisis in the past 10 years which has resulted in many bank closures and liquidations. The list of casualties include: United Merchant Bank, Universal Merchant Bank, Trust Banking Corporation, Intermarket Banking Corporation, Time Bank, Barbican Bank Limited and Royal Bank Limited. The collapse of some major banks in Zimbabwe, coupled with the liquidity crunch resulting from the use of hard currency, affected SME ability to access finance in order to engage in export-oriented productive activities.

As highlighted previously, Zimbabwe's formal economy collapsed in the year 2000. On this subject, Sanderson (2014) concurred with Chipangura and Kaseke (2012) that from the year 2000, there was an economic downturn in Zimbabwe, forcing companies to close down or downsize their operations. Many foreign companies left the country for stable economies such as South Africa.

This new reality saw many Zimbabweans jobless, leading to an increase in new venture start-ups in the form of small businesses for survival purposes. The Zimbabwean government and practitioners have come to acknowledge that SMEs can be the answer to the worsening trade deficit (Mudavanhu, Mubata \& Mudavanhu 2014). Through proper financial support and export training, SMEs have the capacity to lift the economy of Zimbabwe and help create the much needed jobs to deal with high levels of poverty and unemployment. With a static trend in export growth and trade deficits currently facing the country, SMEs can be a tool to improve trade balance and livelihoods (Calabrò \& Mussolino 2011). Sanderson (2014) further stated that to support SME, provisions were made in the Zim-Asset, the Zimbabwean economic blueprint, in which SMEs and cooperatives were scheduled to receive funding and start-up capital.

The next section reviews the literature on the constructs of the study leading to the formulation of hypotheses. After this section, research objectives are presented, and the methodology, results, implications to theory and practice are discussed. Last, the conclusion is also presented.

\section{Small- and medium-sized entity access to finance and exporting behaviour}

The availability of finance is critical to SMEs. Milanzi (2012) revealed that limited access to finance significantly affected the export behaviour of Tanzanian SMEs. Bellone et al. (2010) found that SMEs with better access to finance were more likely to venture into international markets as opposed to those who had poor financial health. In addition, entities with better financial health enjoyed a short decision-making period regarding serving foreign markets as opposed to those with poor financial health.

The findings by Bellone et al. (2010) are contrary to the previous belief that pursuing foreign markets improved the financial position of exporters (Campa \& Shaver 2002; Ganesh-Kumar, Sen \& Vaidya 2001; Greenaway, Guariglia \& Kneller 2007). Ughetto (2008) provided evidence, indicating that SMEs struggle to access external finance targeted for innovation and export development purposes. Because of the uncertainty and risk mix, SMEs find it difficult to present sound business plans that are export oriented and, in the process, they scare away potential funders and this increases the loan application refusal rates (Riding et al. 2010).

In dealing with global markets, there is high commercial risk as opposed to local markets. In such cases, investors shy away when there is no sound strategy and legal framework to protect their finances (Love \& Roper 2015). In that regard, Bellone et al. (2010) concluded that inadequate access to finance acted as a barrier to SMEs' participation in exporting activities. This brings forward the argument that exporting activities can only be pursued by entities that are financially healthy with the capacity to pay for high upfront or sunk entry costs. The thinking here is that when SMEs have access to finance, they gain the ability to improve on their flexibility, they get to improve on their innovation capacity and invest in the needed equipment and technology (Naude \& Chiweshe 2017). When the above is achieved, SMEs will not only be able to improve on their productivity but they will also meet quality standards in line with other firms that are into buying and selling of goods and services on the global market (Chipangura \& Kaseke 2012).

Exporting entities have to incur large sunk entry costs to establish themselves in the global market. Thus, entities who cannot afford to pay for sunk entry costs may not have the privilege to market their offering in the global market (Chaney 2005). This notion is well supported by theory, for example the new-new trade theory. According to the newnew trade theory, the significant trade obstacles faced by entities are in the form of fixed costs that have to be addressed prior to any meaningful trade activities taking place. A study by Moini (2007) provided evidence where non-exporting entities in the USA unanimously singled out high upfront costs as the major factor deterring them from pursuing global markets.

Conversely, pursuing international markets may improve an entity's access to external finance chances (Bellone et al. 2010). First, in principle, entities participating in global markets should be enjoying stable cash flows as opposed to nonexporters. This is because exporters are leveraged against demand-side shocks, given that global markets are imperfectly correlated. In addition, exporters' turnover is internationally diversified (Bridges \& Guariglia 2008; Chingwaru \& Jakata 2015). Second, participating in global markets should send the signal of an entity's efficiency and competitiveness to local funders (Esteve-Pérez \& Rodríguez 2013). Entities with exporting capabilities send the message to local funders as well as international funders that they are the best at what they do. As a result, funders both locally and internationally should at least view exporting as another uncostly method of 
evaluating the profitability potential of an investment. Thirdly, trading in global markets can enhance the entity's access to international financial markets, especially in countries where the entity's goods are being sold. According to Tornell and Westermann (2003), foreign exchange revenues represent a strong collateral security to global investors.

Evidence exists suggesting that inadequate funding of SMEs by state agencies and private investors has been one of the many critical barriers for SMEs to pursue international markets (Gombarume \& Mavhundutse 2014; Pinho \& Martins 2010). In support of the previous notion, relying on data from transition countries, Gashi, Hashi and Pugh (2014) found that adequate access to external funding increased SMEs' propensity and intensity to pursue international markets. Given the above discussion, the following hypothesis was formulated:

$\mathbf{H}_{1}$ : Access to finance has a positive impact on export behaviour of SMEs.

\section{Small- and medium-sized entity access to finance and performance}

In order for SMEs to finance their daily production activities and perform well, a healthy financial position is critical, more importantly, a significant positive networking capital (current assets minus current liabilities) position (Bhunia 2010). Before production activities begin, SMEs need finance for start-up purposes, investing in capital and undertaking research and development activities, among others. After being fully established, finance is required to finance daily activities, for example the purchase of raw materials and payment of current liabilities as they mature. To finance these critical activities, various sources of finance exist, which therefore makes their accessibility more critical to SMEs, as they determine their performance and continued existence. These include formal (long-term and short-term debt, equity from entity owner, among others) and informal sources comprising loans from friends and immediate family members (Fatoki \& Asah 2011).

In accordance with the finance theory, only the permanent portion of working capital should be financed through longterm debt (Gitman 2000). This leaves the financing of nonpermanent working capital to short-term sources of finance, namely trade credit, bank overdraft, tax provisions and shortterm bank loans among other alternative current liabilities that can be used to fund non-permanent working capital requirements (Padachi, Howorth \& Narasimhan 2012).

In situations where a negative net working capital exists, short-term sources of funding could as well be used to finance non-current assets; by so doing, the aggressive approach will have been adopted (Bhattacharya 2001). Research provides evidence that SMEs mostly prefer the use of informal sources of finance (Padachi et al. 2012). This is a strategy which the majority of SMEs implement solely to maintain firm ownership.
Firm performance is directly dependent on access to long-term and short-term performance. In support of the previous statement, Baliamoune-Lutz and Lutz (2017) recently surveyed 25500 female-owned firms (only) in the Middle East and Africa. The results indicate that inadequate access to finance significantly contributed to poor entity performance. Zindiye (2008) concurred and pointed out that because of inadequate access to finance, SMEs are without the capacity to buy quality raw materials to produce quality goods and services that adhere to international standards, expected of firms competing in the global market. In other words, owing to poor access to finance, SMEs find it challenging to live up to their performance outcomes (Karedza et al. 2014).

Vanacker, Collewaert and Zahra (2016), relying on longitudinal data from 162633 European entities across 26 countries, found evidence that slack financial resources (more than the required minimum level for operational purposes) enhanced the entity's performance level. However, the higher the slack level of financial resources, the lower the entity's performance enhancement was. They further provided evidence that in European countries where weak credit rights were found, abundant financial resources had a positive effect on entity performance. Literature reviewed in this section suggests that access to and availability of finance plays a pivotal role in the performance of SMEs. In light of this discussion, the following hypothesis was formulated:

$\mathbf{H}_{2}$ : Access to finance has a positive impact on firm performance of SMEs.

\section{Firm performance and exporting behaviour}

Katsikeas and Skarmeas (2003) pointed out that exporting is critical to SMEs as it can enhance the skills and capabilities of owner or managers. Naude and Chiweshe (2017) concurred and pointed out that in the 21st century, firms are expected to compete in international markets given that more markets have opened up, creating a potential increase in revenue. Thus, by pursuing global markets, SMEs stand to benefit and learn very much from competition (Tambunan 2011). Research by Claver et al. (2007) provides evidence that venturing into international markets is critical for SMEs as it exposes their products to a large potential market. Given that the products are of good quality and conform to international standards, SMEs stand a chance to improve their balance sheet position through retained profits (Naude \& Chiweshe 2017).

An SME's productive capacity is also likely to improve given that the entity will be serving at least one market. Lejárraga et al. (2014) provided evidence indicating that pursuing international markets led to an increase in productivity. As SMEs attempt to avoid losing potential sales to competitors, owing to empty shelves, they are compelled to invest in technology for effective and efficient utilisation of resources through productive innovative means. Productive innovative means are an outcome of further investments in research and development activities (Esteve-Pérez \& Rodríguez 2013). 
Investing in technology is critical as that enables the SME to reduce lead time leading to high productivity (Aw, Roberts \& Winston 2007). Eliasson, Hansson and Lindvert (2012) supported the previous notion. Relying on evidence from 14000 Swedish SMEs, where significant investment in physical capital was pursued for innovation purposes, Eliasson et al. (2012) found that exporting SMEs were performing well as opposed to non-exporters. Thus, SMEs tend to benefit from engaging in exporting activities as it has positive effects on the performance (Chingwaru \& Jakata 2015).

Conversely, the self-selection hypothesis points out that SMEs who perform well are the ones that are most likely to pursue international markets (Wagner 2007). This thinking comes into perspective given that there are fixed costs or barriers to internationalisation. In other words, only entities with the capacity to overcome fixed costs will pursue international markets. Thus, entities who export are better performers than non-exporters (Greenaway \& Kneller 2007), which implies that entities do not export because they enjoy the benefits associated with internationalisation but because they perform well from the beginning (Love \& Roper 2015). High-performers have the capacity to offset fixed costs associated with internationalisation. These fixed costs include costs associated with market research activities, costs for establishing a reliable distribution network, costs of identifying and negotiating with potential partners and costs for adjusting the offering to suit the international markets (Chingwaru \& Jakata 2015).

In agreement with the above notion, Helpman, Melitz and Yeaple (2004) also argued that pursuing international markets is relatively easier for high-performing entities that have the capacity to overcome fixed costs associated with going global. Evidence provided by Aw, Roberts and Xu (2011) indicated that an entity's productivity enhanced its chances of pursuing global markets and engaging in research and development initiatives. Hilmersson (2014) also pointed out that research unanimously agrees that there is a positive relationship between pursuing global markets and SME performance. In light of this debate, the article posits that:

$\mathbf{H}_{3}$ : Firm performance has a positive impact on export behaviour of SMEs.

Fafchamps and Schündeln (2013) examined the relationship between local financial development and firm performance in Morocco; Boermans and Willebrands (2011) analysed the influence of financial constraints on firm performance and Atieno (2009) examined linkages between access to finance and the performance of small-scale enterprises in Kenya. Berman and Hericourt (2009) investigated the influence of access to finance among other finance-related factors and their influence on the entity's decision to buy and sell goods or services at a global stage. Relying on data from 5000 entities plying their trade in emerging and developed countries, Berman and Hericourt (2009) found that availability of finance played a big role in the entity's decision to engage in buying and selling of goods or services at a global stage. Figure 1 presents the proposed conceptual research framework.

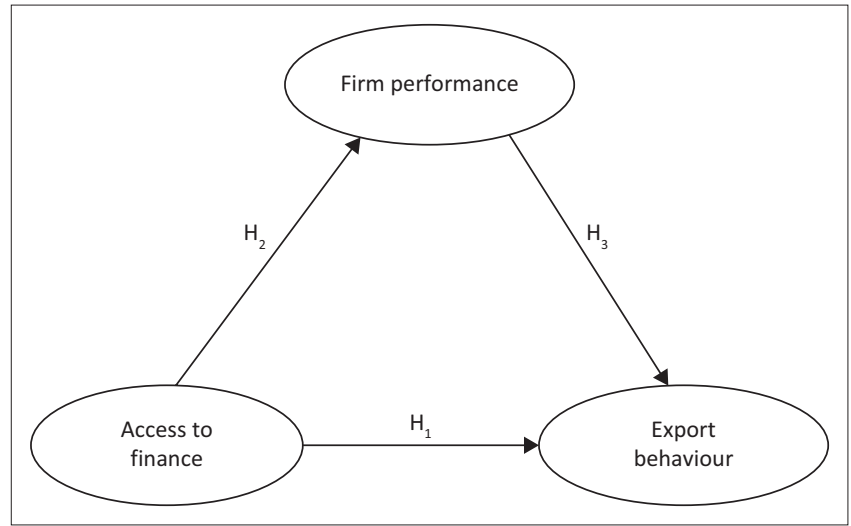

FIGURE 1: Conceptual framework.

Figure 1 presents the posited linear relationships between the three research variables in this article. Access to finance is the predictor variable, firm performance is the mediator variable, while export behaviour is the outcome variable.

\section{Context}

\section{Defining small- and medium-sized entities: The Zimbabwean perspective}

In Zimbabwe, according to the Small Enterprise Development Cooperation (SEDCO 2011), SMEs are business entities with a staff component not exceeding 100 working full time. On the one hand, small entities are categorised as business entities with a staff component of not more than 50 working full time and registered. On the other hand, medium entities are categorised as registered business entities with a staff component of not more than 100 also working full time.

Chipangura and Kaseke (2012) stated that SEDCO no longer utilises the capital and turnover approach to define SMEs because of valuation challenges because of the adoption of a multi-currency system. Small businesses, as referred to by the CZI, cited in Chipangura and Kaseke (2012), have an employment capacity of 1-20 hired employees and an annual turnover of less than US\$4 million. Medium enterprises have an employment capacity of between 20 and 25 hired employees and an annual turnover of US\$5 million. For the purposes of this study, the term SME is defined in accordance with the CZI. The article is motivated by the growing significance of SMEs in the economic development of Zimbabwe, and the continuing limitations they face in their operations.

\section{Small- and medium-sized entity access to finance and exporting behaviour in Zimbabwe}

The exportation of Zimbabwean SME products has drastically decreased over the years since 1999 and performance on international and continental markets has become almost non-existent (Karedza \& Govender 2017). Chingwaru and Jakata (2015) surveyed 41 SMEs in Harare, the capital city of Zimbabwe, and found that for the few SMEs participating in exportation of products, the percentage of exports to total sales is as low as $5 \%$ and that decreased participation in international markets is largely the result of lack of access to finances. 
Mupemhi (2013) stated that among other findings across the 10 provinces of Zimbabwe, SME internationalisation is hindered by the unavailability of funds. Small- and mediumsized entities need funds to internationalise and this practice requires finances to cover costs. Such costs include international market research, development of export markets, international exhibitions, fluctuating foreign demand, shipment costs, insurance and non-payment of delivered goods. Lopez (2007) and EFIC (2008) identified the lack of adequate financial resources as the greatest factor limiting SME internationalisation. Zimbabwe and some Organisation for Economic Cooperation and Development (OECD) and nonOECD countries such as Brazil, Russia, India, China and Israel have come up with new schemes that support SME exporting performance. The plans cater for direct financing, provision of soft loans through banks or government agencies to cover pre- and post-shipment costs and the provision of insurance to cushion against non-payment after deliveries (Mupemhi 2013; OECD 2009).

\section{Small- and medium-sized entity access to finance and performance in Zimbabwe}

Access to finance is the key determinant of SME performance in Zimbabwe (World Bank Ghana Office 2013). Fanta et al. (2017), in their study on four SADC countries, namely Malawi, Mozambique, Zambia and Zimbabwe, highlighted that about $50 \%$ of small business owners in Zimbabwe start and grow their entrepreneurial endeavours out of their own money and a third out of informal finance. He mentioned that in Zimbabwe, a maximum of only $2.3 \%$ of SMEs have access to bank credit, $11.3 \%$ from informal finances, $1.6 \%$ from other formal sources and none from trade.

The above scenario implies that those individuals without access to the stated sources lack finances for start-up and growth, and hence they only perform poorly regardless of how much enthusiasm they start off with. This is so because informal loans are small; they are mostly used in small business performance for financing operations (working capital) rather than growth (expansion) (Fanta 2012); and informal lenders charge unreasonably high interest rates that erode profit of small firms, according to Bolnick (1992).

The lack of access to finance is the primary obstacle (constituting $50 \%$ obstruction) to growth in Zimbabwe followed by marketrelated problems (13\%) such as competition, lack of customers, lack of enough stock, and so on, and other problems (37\%). Gombarume (2014) in a study on 100 SMEs in Chitungwiza, Zimbabwe, also noted that most of the SMEs were not getting enough financial support from financial institutions and were thus not performing well. It was recommended that the government should set up a loan guarantee scheme and SMEs should formalise their activities to get financial support from financial institutions.

Tinarwo (2016) highlighted that because of the buyer denominated market, where buyers negotiate and bargain until prices are lowered unprofitably, the operators of SMEs in
Zimbabwe have resorted to producing substandard products. This enables them to conserve costs, leading to poor SME performance because customers begin to lose confidence in doing business with SMEs operating on the market and this forces them to source alternatives.

\section{Firm performance and exporting behaviour in Zimbabwe}

There is not much literature on the link between firm performance and exporting behaviour for Zimbabwe. However, Van Biesebroeck (2005) in a study of nine sub-Saharan African manufacturing countries, including Zimbabwe, found that exporters are systematically more productive than domestically oriented producers in the same country and industry and that exporters improve their relative performance after they enter foreign markets. On the other hand, Biggs and Shah (2006) also highlighted that most sub-Saharan countries penetrate the international market through the formation of tight networks; however, this increases the performance of the local SMEs at the expense of the other outsider nations with whom trade is being conducted. This therefore leaves room for further investigation into a truer model of the relationship between firm performance and exporting behaviour, particularly in the case of Zimbabwe.

\section{Research objectives}

This article assessed:

- the impact of access to finance on the export behaviour of SMEs in Harare, Zimbabwe;

- the impact of access to finance on SME performance;

- the impact of firm performance on SME export behaviour.

\section{Research methodology}

This study followed a descriptive analysis because the underlying relationships of the research variables (access to finance, firm performance and export behaviour) surrounding the problem were known (Cant et al. 2003). A quantitative research technique was used with the aim of obtaining SME owners' or managers' understanding of the impact of access to finance on their firm's performance and export behaviour in Harare, Zimbabwe. To gather primary data, a self-administered questionnaire was used. The measures used in the questionnaire were adopted from extant literature that investigated issues related to the study's objectives.

\section{Sample and data collection}

Self-administered questionnaires were used for the collection of data from the furniture manufacturing SME owners or managers. The SME owners or managers whose businesses are located in Harare, particularly the Zengeza and Glenview clusters; who are involved in the direct manufacturing of wood and steel furniture, with a firm of 2 years old or more; and who comply with the definition of a small and medium enterprise contained in the CZI were the respondents in this study. The Harare Municipality authorities were approached 
to obtain the sampling frame which comprised a list of 1520 enterprises registered for both Glenview (1300 SMEs) and Zengeza (220). Stratified random sampling was used to select two strata on the basis of wood furniture manufacturer and steel furniture manufacturer. Wood furniture manufacturers constituted $70 \%$ of the population, while steel furniture manufacturers accounted for 30\% (Muponda 2012). Simple random sampling was then used to select the single sample for all the targeted SMEs and a sample size of 245 SMEs was selected, assuming a 93\% confidence interval. Of the 183 SMEs, $86 \%$ were from the Glenview cluster, while $14 \%$ were from Zengeza. Using both the stratified and simple random probability sampling enhanced the sample representativeness of the furniture manufacturing SME population in Harare. Of the 245 questionnaires issued, a total of 159 (of which 135 were from the Glenview cluster and 24 were from Zengeza) were returned and usable for data analysis for this article. Thus, on average, the response rate was $65 \%$ which is acceptable. The self-administered questionnaires were designed in a way that allowed the researchers to perform confirmatory factor analysis indices, particularly the chi-square or degree of freedom (CS/DF), the comparative fit analysis and the incremental index of fit (IIF) (Hove, Sibanda \& Pooe 2014).

\section{Measurement instrument and questionnaire design}

The research measures for this article were operationalised relying on extant literature. Necessary adjustments were made so as to align the concepts with the study's objectives. To measure access to finance, four items were adapted from Contessi and De Nicola (2012) and Spicer (2010). To measure firm performance, nine items were adopted from Contessi and De Nicola. Finally, to measure SME export behaviour, five items were adapted from Ruiz-Fuensanta (2010). A fivepoint Likert-scale, with coding values ranging from $1=$ strongly disagree to $5=$ strongly agree, was used in all the measurement items.

\section{The study measures}

\section{Export behaviour of small- and medium-sized entities}

Different studies have used different indicators to operationalise export behaviour. Milanzi (2012) was of the opinion that export behaviour has been studied widely using different conceptualisations and measurements. Basile (2000) and Wakelin (1998) defined export behaviour as an entity's likelihood to buy and sell goods or services in a global market and also as the propensity to export for the exporting firms. For the present study, the authors also define export behaviour as both the likelihood to engage in buying and selling of goods or services in a global market and the propensity to sell goods or services in a global market. The authors employed five items used in RuizFuensanta (2010), namely international experience, timing of entry in export markets, export intensity, management's attitudes and perceptions and export motivation.

\section{Access to finance}

Unavailability of finance was singled out as the main reason behind the high failure of SMEs in Van Eeden et al.'s (2001) study. Five years later, Beck and Demirguc-Kunt (2006) also found similar results. For newly established SMEs with no credit record, access to finance could be very difficult especially when the owner has few assets to guarantee lenders that he or she has the capacity to service the loan. The other challenge is that of moral hazard, that is to say, SME owners or managers may divert the money to other undisclosed projects. This challenge is fuelled by poor financial control measures highly exhibited among SMEs (Stokes \& Wilson 2006). In this study, access to finance was measured by the following four items adopted from Contessi and De Nicola (2012) and Spicer (2010): (1) access to longterm debt finance, (2) finance and other sources to expand decisions that influence the place and time to export, (3) access to credit as an obstacle to business and cash flow as well as (4) payment risks that influence the decisions of the place and time to export.

\section{Firm performance}

To define entity performance, the study by Melville, Kraemer and Gurbaxani (2004) focused on the impact of technology on various business functions. Firstly, when the firm has invested in technology, the thinking is that it should be enjoying reasonable production costs. Secondly, the entity must be able to at least compete effectively in the market, and thirdly, the entity should be able to improve its revenue base. Research has also introduced the entity's marketing performance in an attempt to broaden the definition of performance, for example Homburg and Pflesser (2003), Hooley et al. (2005), Wong and Merrilees (2007) and Hove et al. (2014). In this study, performance was viewed as a unidimensional construct and was measured through objective performance dimensions, namely revenue size, revenue growth, average returns, growth in returns and the entity's market share.

\section{Results \\ Respondent profile}

The demographic and SME profile information is presented in Table 1. The SME owners or managers who participated in this survey were asked to provide information on their gender, age and educational background. In addition, some business profile information was obtained from the following: the firm age, number of employees and average annual turnover. The respondents were predominantly males (92\%), with $8 \%$ females. With regard to age, $29 \%$ of the SME owners or managers were 30 years and below, $64 \%$ were between the ages of 31 and 60 , while $7 \%$ were older than 60 years. A majority of the participant SME owner or managers (56\%) had secondary education qualifications, followed by diploma and certificate holders (28\%). Of these SME owners or managers, $9 \%$ had degrees and postgraduate qualifications, $4 \%$ had no formal education at all, while $3 \%$ had primary education. 
TABLE 1a: Sample demographic characteristics

\begin{tabular}{lcc}
\hline Characteristics & Frequency & Percentage \\
\hline Gender & 146 & 92 \\
Male & 13 & 8 \\
Female & 159 & 100 \\
\hline Total & & \\
\hline Age & 46 & 29 \\
$\leq 30$ & 101 & 64 \\
$31-60$ & 12 & 7 \\
$>60$ & 159 & 100 \\
\hline Total & & 4 \\
Education qualification & 7 & 3 \\
No education & 5 & 56 \\
Primary education & 89 & 28 \\
Secondary education & 45 & 9 \\
Diploma or certificate & 13 & 100 \\
Degree or postgraduate & 159 & \\
degree & &
\end{tabular}

TABLE 1b: Sample small- and medium-sized entity profile characteristics.

\begin{tabular}{lcc}
\hline Characteristics & Frequency & Percentage \\
\hline Firm age & 115 & 72 \\
2-10 years & 33 & 21 \\
11-20 years & 11 & 7 \\
Above 20 years & 159 & 100 \\
\hline Total & & \\
\hline Number of employees & 129 & 81 \\
Less than 20 & 30 & 19 \\
20-35 & 159 & 100 \\
\hline Total & & \\
\hline Average annual turnover & 119 & 75 \\
Less than 4 million & 40 & 25 \\
Less than 5 million & $\mathbf{1 5 9}$ & $\mathbf{1 0 0}$ \\
\hline Total & &
\end{tabular}

Regarding the SME profiles, $72 \%$ of the SMEs were aged between 2 and 10 years, 21\% were between 11 and 20 years, while $7 \%$ had been in business for more than 20 years. Of these SMEs, $81 \%$ employ fewer than 20 workers, while $19 \%$ employ between 20 and 35 workers. About $75 \%$ of the surveyed SMEs generate an average annual turnover of less than R4 million, while $25 \%$ have a turnover of less than R5 million per year. The SME owners or managers were also asked whether their firms have access to finance (long-term loans). A majority (81\%) of these SME owners or managers indicated that they do not have any access to finance (long-term loans) for their expansion and growth, while $8 \%$ indicated that they have access and $11 \%$ were neutral regarding their access to finance. Some of the reasons that were provided for lack of access to finance include: lack of collateral security, absence of business plans, poor bookkeeping skills and lack of transparency. The SME owners or managers were also asked whether their firms are exporting or intending to export their goods. The findings revealed that $77 \%$ of these SMEs indicated that they are not exporting and have no intentions of exporting their goods, $12 \%$ are exporting and are intending to export, while $11 \%$ were indifferent with regard to their intentions to export. Financial constraints increased competition in international markets and high transportation costs were the most cited reasons for not exporting and not intending to export.

\section{Data analysis and results}

A structural equation modelling (SEM) technique that employed Smart partial least squares (PLS) statistical software was used to test the hypothesised impact of access to finance on firm performance and the export behaviour of SMEs. Smart PLS was used in this study as it allows the use of relatively smaller samples compared to other software such as Amos and Lisrel. This study used a sample of 159 SME owners or managers which is relatively smaller than the sample sizes required by other SEM software to obtain robust results.

\section{Measurement model}

Reliability refers to the similarity of results provided by the independent but comparable measures of the same object or construct, or an index of consistence (Churchill \& Iacobucci 2010:258). The primary measures of reliability in this study included composite reliability (CR) and Cronbach's alpha values. Validity was measured in two categories: convergent and discriminant. Convergent validity was measured using the item or factor loadings exceeding 0.5 on their respective (priori) constructs (Chinomona 2013). Discriminant validity was measured using the average variance extracted (AVE) values and ensuring that there were no significant interresearch variable cross-loadings (Chin 1998). Smart PLS statistical software was used to perform a confirmatory factor analysis (CFA) and estimating the SEM for testing the research hypotheses. The CFA results are reported in Table 2 and Figure 2, while the SEM results are presented in Table 4 and Figure 2.

Composite reliability and the Cronbach's alpha values were primarily used to assess the reliability of the three research constructs measures, as previously noted in this article. The CR values ranged from 0.786 to 0.836 , while the Cronbach's alpha values ranged between 0.735 and 0.877 (see Table 2). All these reliability measures of CR and Cronbach's alpha were above the recommended threshold value of 0.7 , thereby confirming the reliability of the three research construct measures (Nunnally \& Bernstein 1994).

Convergent validity as noted earlier was measured 'by checking whether individual factor loadings for each corresponding research construct were above the recommended value of $0.5^{\prime}$ (Anderson \& Gerbing 1988; Hove et al. 2014). As shown in Table 2, only one item (access to finance [AF] 1 -SMEs' access to long-term debt) among the four measures of access to finance had a factor loading (0.953) of above the recommended threshold of 0.5. Firm performance, just like access to finance, had one item with a factor loading of above the acceptable value of above 0.5 . The item is profitability (FP 2) and it had a factor loading of 0.653 . All the export behaviour items, except for export timing ((EB 2) which had a negative factor loading -0.823), had positive factor loadings of above the recommended threshold of above 0.5 , and ranged between 0.622 and 0.907. In light of the above, it can therefore be concluded that most of the items used to measure the three 
TABLE 2: Accuracy analysis statistics.

\begin{tabular}{|c|c|c|c|c|c|c|c|c|}
\hline Research construct & Variable & LV Index value & $R^{2}$ value & Cronbach's $a$ value & CR value & AVE value & Communality & Factor loading \\
\hline \multirow[t]{4}{*}{$\mathrm{AF}$} & AF 1 & 2.844 & 0.000 & 0.735 & 0.836 & 0.602 & 0.302 & 0.953 \\
\hline & AF 2 & & & & & & & 0.175 \\
\hline & AF 3 & & & & & & & 0.483 \\
\hline & AF 4 & & & & & & & 0.187 \\
\hline \multirow[t]{9}{*}{ FP } & FP 1 & 4.995 & 0.077 & 0.801 & 0.728 & 0.775 & 0.175 & 0.144 \\
\hline & FP 2 & & & & & & & 0.031 \\
\hline & FP 3 & & & & & & & 0.653 \\
\hline & FP 4 & & & & & & & 0.128 \\
\hline & FP 5 & & & & & & & 0.458 \\
\hline & FP 6 & & & & & & & -0.387 \\
\hline & FP 7 & & & & & & & -0.543 \\
\hline & FP 8 & & & & & & & -0.518 \\
\hline & FP 9 & & & & & & & -0.431 \\
\hline \multirow[t]{4}{*}{ EB } & EB 1 & 0.952 & 0.583 & 0.877 & 0.786 & 0.675 & 0.675 & 0.622 \\
\hline & EB 3 & & & & & & & 0.907 \\
\hline & EB 4 & & & & & & & 0.878 \\
\hline & EB 5 & & & & & & & 0.800 \\
\hline
\end{tabular}

Note: AF, access to finance; FP, firm performance; EB, export behaviour. CR, composite reliability; AVE, average variance reliability* scores: 1 - strongly disagree; 2 - disagree; 3 - neutral; 4 - agree; 5 - strongly agree; LV, latent variable.

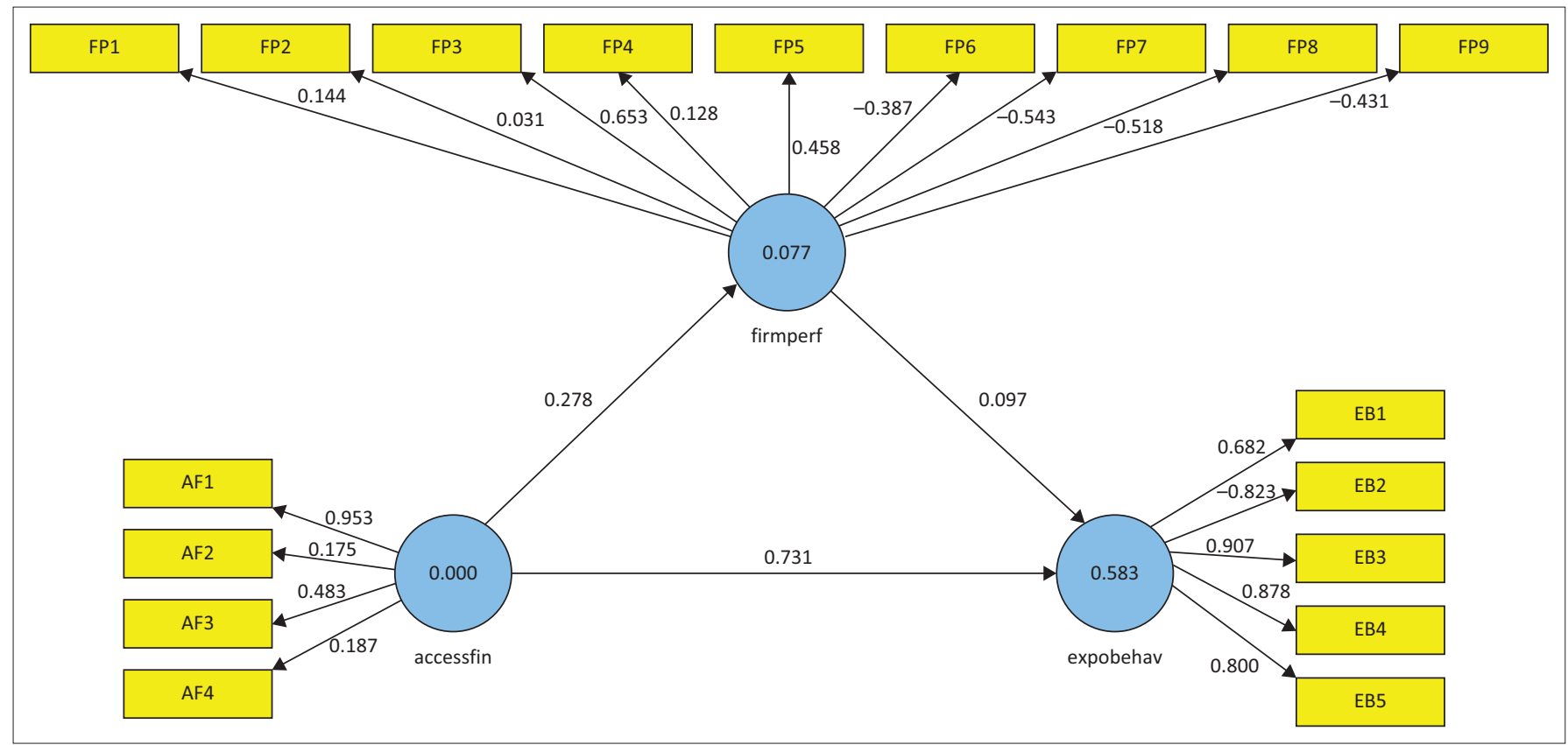

$A F$, access to finance; $F P$, firm performance; $E B$, export behaviour.

FIGURE 2: Measurement and structural model results.

research variables of this article measured more than 50\% of the variables of access to finance, firm performance and export behaviour in SMEs.

Also, as previously noted, the presence of discriminant validity in the items was measured by the AVE values greater than 0.5 (Fornell \& Larcker 1981; Hove et al. 2014). As shown in Table 2, all the AVE values in this study ranged from 0.602 to 0.775 . However, in order to ensure the existence of satisfactory discriminant validity between the research variables, the square root of the AVE of each factor was calculated and, as required, they exceeded the correlations between that factor and all other factors (Fornell \& Larcker 1981). In this study, the squared roots of AVE ranged from 0.776 to 0.880 , thereby exceeding the correlations between
TABLE 3: Inter-construct correlation matrix.

\begin{tabular}{lccc}
\hline Research constructs & AF & FP & EB \\
\hline AF & 1.000 & - & - \\
FP & 0.278 & 1.000 & - \\
EB & 0.758 & 0.301 & 1.000 \\
\hline
\end{tabular}

$A F$, access to finance; $F P$, firm performance; $E B$, export behaviour.

the three research constructs, which ranged between 0.278 and 0.758 (see Table 3). This further confirms the existence of discriminant validity. Above all, these results 'confirm the reliability and validity of the construct measurements used' (Hove et al. 2014:170).

Some of the criticisms on Smart PLS include its inability to provide the goodness-of-fit $(\mathrm{GoF})$ measures for the full 
path model. In addition, it only provides the $R^{2}$ values for the dependent variables (firm performance and export behaviour in this article). However, this study calculated it using a global GoF method, which takes into account both the quality of measurement and the structural model, as proposed by Tenenhaus, Amato and Esposito Vinzi (2004). The following formula was used:

$$
\begin{aligned}
& \text { Goodness-of-fit }={\sqrt[2]{\left(\text { average of all AVE values } \times \text { average of all } R^{2}\right.}}^{2} \\
& =\sqrt[2]{0.684 \times 0.220} \\
& =0.387
\end{aligned}
$$

Based on the calculations above, the global GoF for this study is 0.387 which is above the acceptable 'threshold of 0.36 ' suggested by Wetzels, Odekerken-Schroder and Van Oppen (2009) (Hove et al. 2014). Thus, it can be concluded that the research model provides an overall GoF. Figure 2 and Table 4 presented in the next section help in the discussion of the hypotheses testing results.

H1: Access to finance has a positive impact on export behaviour of SMEs

This study posits a positive and significant linear relationship between accesses to finance and SMEs' export behaviour in Harare, Zimbabwe. Figure 2 and Table 4 present the findings on H1. As revealed in Figure 2, H1 has a positive path coefficient of 0.731 . The positive path coefficient of 0.731 exceeds the recommended threshold value of 0.2 , thus validating the posited positive impact of access to finance on SMEs' export behaviour. Table 4 reports a $T$-statistic value of 11.891 for the posited association between access to finance and SME export behaviour. The $T$-statistic of 11.891 is greater than the recommended and acceptable threshold of 2.0 (Chinomona 2013), thus indicating that access to finance (debt) by SMEs has a significant and positive impact on their export behaviour. This means that if, on the one hand, SMEs lack access to finance, they will export less or will not export their goods at all. On the other hand, their access to finance such as long-term loans will enable the SMEs to export more or intend to export more. Thus, the findings in Table 4 and Figure 2 support $H_{1}$ because the two criteria of significance and positive path coefficient are met. As posited, the findings of this study suggest that access to finance can enhance the export behaviour of SMEs, through increased experience in the export market, not postponing their export intentions, better management perceptions and attitude towards exporting and higher export intensity. These findings are consistent with Muponda's (2012) reasoning, which was that lack of access to adequate finance in the form of both longterm loans and equity capital explains why all the firms (including SMEs) reported that they had not established any export markets for their products, even though they had potential to do so. In light of the above, this study therefore strongly validates and supports the hypothesis that access to finance has a positive impact on export behaviour of SMEs in Harare, Zimbabwe.

H2: Access to finance has a positive impact on firm performance of small- and medium-sized entities

A positive and significant impact of access to finance on firm performance of SMEs was also hypothesised in this article. The SEM results that validate or invalidate this relationship are shown in Figure 2 and Table 4 as earlier noted. Figure 2 shows a positive path coefficient of 0.276 for the posited linear relationship between access to finance and firm performance. The path coefficient of 0.276 exceeds the recommended path coefficient threshold of 0.2 , thus validating the hypothesised positive impact of access to finance on firm performance of SMEs. Table 4, however, reports a weaker $T$-statistic value of 1.632 for the posited linear relationship between access to finance and firm performance of SMEs, which falls below the recommended threshold value of 2.0. This shows that the positive impact of access to finance on SMEs' firm performance is insignificant. Thus, although there is a valid positive path coefficient supporting the posited positive impact of access to finance on SMEs' firm performance, the $T$-statistics of less than 2.0 renders $\mathrm{H} 2$ unsupported for insignificance. This could be because there are factors that explain firm performance of SMEs other than their access to finance. Some of these factors include their access to market, technology and infrastructure to name but a few. The findings suggest that access to finance on its own cannot significantly explain the profitability of SMEs; other non-finance factors should be taken into consideration. As such, this study invalidates and fails to support the hypothesis that states that access to finance has a positive impact on firm performance of SMEs. Thus, the study fails to reject the null hypothesis that claims that access to finance has a negative impact on firm performance.

H3: Firm performance has a positive impact on export behaviour of small- and medium-sized entities

This study also hypothesised that firm performance has a positive and significant impact on SME export behaviour. As earlier seen in Figure 2, a weaker positive path coefficient of 0.097 is reported for H3. The path coefficient falls below the recommended 0.2, thus invalidating the H3. Table 4 complements the weaker and invalidated positive path coefficient in Figure 2, with a weaker $T$-statistic value of 0.934, which falls below the acceptable threshold value of 2.0. This implies that firm performance has a weaker insignificant positive impact on the export behaviour of SMEs. These findings can be explained by the fact that there are factors that explain the export behaviour of SMEs other than their

\begin{tabular}{|c|c|c|c|c|}
\hline Proposed hypothesis relationship & Hypothesis & Path coefficients & $T$-Statistics & Rejected or supported \\
\hline Access to finance (AF) $\rightarrow$ Export behaviour (EB) & $\mathrm{H} 1$ & 0.731 & 11.891 & Supported \\
\hline Access to finance (AF) $\rightarrow$ Firm performance (FP) & $\mathrm{H} 2$ & 0.276 & 1.632 & Not supported \\
\hline Firm performance $(\mathrm{FP}) \rightarrow$ Export behaviour (EB) & $\mathrm{H} 3$ & 0.097 & 0.934 & Not supported \\
\hline
\end{tabular}
profitability. Some of the factors include access to finance,

TABLE 4: Results of structural equation model analysis. 
access to foreign markets, access to competitive technology and networking skills, to mention but a few. Thus, this study invalidates and fails to support the hypothesis that postulates that firm performance has a positive impact on export behaviour of SMEs. As such, the study fails to reject the null hypothesis that claims that firm performance has a negative impact on export behaviour.

\section{Implications for policy}

The validation of the hypothesis that posited that access to finance has a positive impact on exporting behaviour (H1) leads to the following recommendation: To help the country reduce the balance of trade deficit and improve employment creation, the government must do more to improve access to finance, essentially for SMEs that are potential exporters by offering loans. Also, acknowledging the government efforts to support SMEs through the SEDCO and the ministry of small to medium enterprises, more work still needs to be done if the country is to benefit fully from the contribution of small businesses. Spicer (2010) argued that it is not enough that initiatives exist but there must be clear routes to market and awareness among potential beneficiaries and their intermediaries that they can access them. In the same line of reasoning, the government of Zimbabwe and all the other decision makers need to put systems in place that will prioritise the need to have clear routes to market and increase awareness among SME owners and managers along with their intermediaries, in order to realise maximum benefits from the exporting SMEs. In addition, the government must assist SMEs with trade promotion assistance to enable them in the management of costs associated with the export market.

\section{Conclusion}

This article concludes that access to finance has a positive impact on export behaviour of SMEs. It also concludes that access to finance has a negative impact on firm performance of SMEs. Lastly, the article further concludes that firm performance has a negative impact on export behaviour of SMEs.

\section{Limitations and future research direction}

This article makes a contribution towards understanding the exporting behaviour of SMEs in Zimbabwe, especially that of the furniture manufacturers. The study, however, was limited to only the Harare metropolitan province and furniture manufacturing SMEs. Future studies may extend the scope of the study to other provinces and other types of SMES.

The invalidation of $\mathrm{H}_{2}$ and $\mathrm{H}_{3}$ offers an interesting area for study. The weak positive relationship between access to finance and firm performance might be because of many factors. Further studies may look into the combined effect of access to finance and other factors on firm performance. In addition, future studies may consider the indirect effect of firm performance and other factors (e.g. SME demographic profile) on the relationship between access to finance and exporting behaviour.

\section{References}

Abor, J. \& Quartey, P., 2010, 'Issues in SME development in Ghana and South Africa', International Research Journal of Finance and Economics 39(6), 215-228.

Anderson, J.C. \& Gerbing, D.W., 1988, 'Structural equation modelling in practice: A review and recommended two step approach', Psychological Bulletin 103(3), 411-423. https://doi.org/10.1037/0033-2909.103.3.411

Atieno, R., 2009, Linkages, access to finance and the performance of small-scale enterprises in Kenya, Working research Paper No. 2009/06, United Nations University, Tokyo, Japan.

Ayyagari, M., Juarros, P., Martinez Peria, M.S. \& Singh, S., 2016, Access to finance and job growth: Firm-level evidence across developing countries, World Bank Policy Research Working Paper 6704, Washington, DC: The World Bank.

Aw, B.Y., Roberts, M.J. \& Winston, T., 2007, 'Export market participation, investments in R\&D and worker training, and the evolution of firm productivity', The World Economy 30, 83-104. https://doi.org/10.1111/j.1467-9701.2007.00873.x

Aw, B.Y., Roberts, M.J. \& Xu, D.Y., 2011, 'R\&D investments, exporting, and productivity dynamics', American Economic Review 101, 1312-1344. https://doi.org/10.1257/ aer.101.4.1312

Baliamoune-Lutz, M. \& Lutz, S., 2017, Financing and performance of female-owned firms in middle Eastern and African economies, Working Paper, Instituto Complutense de Analisis, Örebro.

Basile, R., 2000, 'Export behaviour of Italian manufacturing firms over the nineties: The role of innovation', Elsevier Research Policy 30, 1185-1201. https://doi.org/ 10.1016/S0048-7333(00)00141-4

Beck, T. \& Demirguc-Kunt, A., 2006, 'Small and medium-size enterprises: Access to finance as a growth constraint', Journal of Banking \& Finance 30, 2931-2943. https://doi.org/10.1016/j.jbankfin.2006.05.009

Bellone, F., Musso, P., Nesta, L. \& Schiavo, S., 2010, 'Financial constraints and firm export behaviour', The World Economy 33(3), 347-373. https://doi.org/10.1111/ j.1467-9701.2010.01259.x

Berman, N. \& Hericourt, J., 2009, 'Financial factors and the margins of trade: Evidence from cross-country firm-level data', Journal of Development Economics 93, 206217. https://doi.org/10.1016/j.jdeveco.2009.11.006

Bernard, A., Stabilito, A. \& Yoo, J.D., 2010, Access to finance and exporting behavior in transition countries, Working Paper No. 456, Kiel Institute for the World Economy, Kiel, Germany.

Bhalla, A., Davies, R., Mabugu, M. \& Mabugu, R., 1999, Globalisation and sustainable human development: Progress and challenges for Zimbabwe, Occasional Paper, Unctad/Edm/Misc.128, United Nations Conference on Trade and Development.

Bhattacharya, H., 2001, Working capital management: Strategies and techniques, Prentice Hall, New Delhi.

Bhunia, A., 2010, 'A trend analysis of liquidity management efficiency in selected private sector Indian steel industry', International Journal of Research in Commerce and Management 1(5), 618-628.

Biggs, T. \& Shah, M.K., 2006, 'African SMES, networks, and manufacturing performance', Journal of Banking \& Finance 30(11), 3043-3066. https://doi. org/10.1016/j.jbankfin.2006.05.004

Boermans, M.A. \& Willebrands, D., 2011, Firm performance under financial constraints and risks: Recent evidence from micro finance clients in Tanzania, HU University of Applied Sciences, Utrecht.

Bolnick, B.R., 1992, 'Moneylenders and informal financial markets in Malawi', World Development 20(1), 57-68. https://doi.org/10.1016/0305-750X(92)90136-J

Bridges, S. \& Guariglia, A., 2008, 'Financial constraints, global engagement, and firm 23 survival in the United Kingdom: Evidence from micro data', Scottish Journal of Political Economy 55(4), 444-464. https://doi.org/10.1111/j.1467-9485.2008. 00461.x

Calabrò, A. \& Mussolino, D., 2011, 'How do boards of directors contribute to family SME export intensity? The role of formal and informal governance mechanisms', Journal of Management \& Governance 17(2), 363-403. https://doi.org/10.1007/ s10997-011-9180-7

Campa, J.M. \& Shaver, J.M., 2002, 'Exporting and capital investment: On the strategic behaviour of exporters', Discussion Paper No. 469, IESE Business School, University of Navarra.

Cant, M., Gerber-Nel, C., Nel, D. \& Kotze, T., 2003, Marketing research, New Africa Books (Pty) Ltd, Cleremont.

Carbó-Valverde, S., Rodríguez-Fernández, F. \& Udell, G.F., 2016, 'Trade credit, the financial crisis, and SME access to finance', Journal of Money, Credit and Banking 48(1), 113-143. https://doi.org/10.1111/jmcb.12292

Chaney, T., 2005, Liquidity constrained exporters, Mimeo, University of Chicago, Chicago, IL.

Chin, W.W., 1998, 'Issues and opinion on structural equation modelling', MIS Quarterly 22(1), 7-16.

Chingwaru, T., 2014, 'Impact of trade and economic liberalisation on policy reforms on the operations of selected small to medium enterprises (SMEs) in Zimbabwe; A comparative study with South Africa's experiences', Unpublished DBA thesis, Durban University of Technology, Durban, South Africa.

Chingwaru, T. \& Jakata, O., 2015, 'Factors restraining small to medium enterprises (SMEs) from engaging in export market: The case of manufacturing SMEs in Harare, Zimbabwe', International Journal of Science and Research 4(10), 643-647.

Chinomona, R., 2013, 'Dealers' legitimate power and relationship quality in Gaunxi distribution channel: A social rule system theory perspective', International Journal of Marketing Studies 5, 42-58. https://doi.org/10.5539/ijms.v5n1p42 
Chipangura, A. \& Kaseke, N., 2012, 'Growth constraints of small and medium enterprises (SMEs) at Glenview Furniture Complex (GFC) in Harare (Zimbabwe)', International Journal of Marketing and Technology 2(6), 40-83.

Churchill, D.A. \& lacobucci, D., 2010, Market research: Methodological foundations, South-Western Cengage Learning, Boston, MA.

Claver, E., Lopez, M.D., Molina, J.F. \& Tarí, J.J., 2007, 'Environmental management and firm performance: A case study', Journal of Environmental Management 84(4), 606-619. https://doi.org/10.1016/j.jenvman.2006.09.012

Confederation of Zimbabwe Industries (CZI), 2011, Manufacturing survey report Confederation of Zimbabwe Industries, Harare, Zimbabwe, pp. 1-23.

Confederation of Zimbabwe Industries (CZI), 2015, Manufacturing survey report Confederation of Zimbabwe Industries Harare, Zimbabwe, pp. 1-26.

Contessi, F. \& De Nicola, S., 2012, What do we know about the relationship between access to finance and international trade? Working Paper 2012-054B, Federal Reserve Bank of St. Louis, St. Louis, MO.

Damoah, O.B.O., 2011, 'The export behaviour of small and medium-sized manufacturing firms: Evidence from the garment and textile industry of Ghana', Unpublished Doctor of Philosophy Thesis, Cardiff School of Management, The University of Wales, Llandaff Cardiff, UK, pp. 1-408.

Deijl, C., De Kok, J. \& Veldhuis-Van Essen, C., 2013, 'Is small still beautiful? Literature review of recent empirical evidence on the contribution of SMEs to employment creation', viewed 20 April 2017, from http://lup.lub.lu.se/record/cfac576e-a5c4 4802-b5f3-7989d9bffd46

Edmunds, S.E. \& Khoury, S.J., 1986, 'Exports: A necessary ingredient in the growth of small business firms', Journal of Small Business Management 24, 54.

EFIC, 2008, Global readiness index-national results report, April, viewed 26 February 2018, from https://slideblast.com/efic-global-readiness-index-national-report2018, from https://slideblast.com/efic-glob
april-2008 5978290f1723dd049a427558.html

Eliasson, K., Hansson, M. \& Lindvert, M., 2012, 'Do firms learn by exporting or learn to export? Evidence from small and medium-sized enterprises', Small Business Economics 39, 453-472. https://doi.org/10.1007/s11187-010-9314-3

Esteve-Pérez, S. \& Rodríguez, D., 2013, 'The dynamics of exports and R\&D in SMEs', Small Business Economics 41(1), 219-240. https://doi.org/10.1007/s11187-012 9421-4

Fafchamps, M. \& Schundeln, M., 2013, 'Local financial development and firm performance: Evidence from Morocco', Journal of Development Economics 103 15-28. https://doi.org/10.1016/j.jdeveco.2013.01.010

Fanta, A.B., 2012, 'Banking reform and SME financing in Ethiopia: Evidence from the manufacturing sector', African Journal of Business Management 6(19), 6057-6069.

Fanta, A.B., Mutsonziwa, K., Berkowitz, B., Maposa, O., Motsomi, A. \& Khumalo, J. 2017, Small business performance: Does access to finance matter?, Policy Research Paper No. 05/2017, Midrand, Finmark Trust, File Ref: 16848.

Fatoki, O.O. \& Asah, F., 2011, 'The impact of firm and entrepreneurial characteristics on access to debt finance by SMEs in King Williams' Town, South Africa', Internationa Journal of Busine

Ferrando, A. \& Mavrakis, E., 2017, 'Non-bank financing for Euro area companies during the crisis', in Access to bank credit and SME financing, pp. 3-28, Springe International Publishing, Cham.

Fornell, C. \& Larcker, D.F., 1981, 'Evaluating structural equation models with unobservable variables and measurement error', Journal of Marketing Research 27, 39-50. https://doi.org/10.2307/3151312

Ganesh-Kumar, A., Sen, K. \& Vaidya, R., 2001, 'Outward orientation, investment and finance constraints: A study of Indian firms', Journal of Development Studies 37(4), 133-149. https://doi.org/10.1080/00220380412331322071

Gashi, P., Hashi, I. \& Pugh, G., 2014, 'Export behaviour of SMEs in transition countries', Small Business Economics Journal 42, 407-435. https://doi.org/10.1007/s11187 013-9487-7

Gerlach-Kristen, P., O'Connell, B. \& O'Toole, C., 2015, 'Do credit constraints affect SME investment and employment?', The Economic and Social Review 46(1), 51-86.

Gitman, L.J., 2000, Principles of managerial finance, 9th edn., Addison Wesley \& Longman, Reading, MA.

Gombarume, F., 2014, 'Challenges faced by small to medium scale enterprises: A case study of Chitungwiza, Zimbabwe', Greener Journal of Business and Management Studies 4(4), 103-107. https://doi.org/10.15580/GJBMS.2014.4.102113910

Gombarume, F.B. \& Mavhundutse, S., 2014, 'Challenges faced by small to medium scale enterprises: A case study of Chitungwiza, Zimbabwe', Greener Journal of
Business and Management Studies, 4(4), 103-107. https://doi.org/10.15580/ Business and Management
GJBMS.2014.4.102113910

Greenaway, D., Guariglia, A. \& Kneller, R., 2007, 'Financial factors and exporting decisions', Journal of International Economics 73(2), 377-395. https://doi. org/10.1016/j.jinteco.2007.04.002

Greenaway, D. \& Kneller, R., 2007, 'Firm heterogeneity, exporting and foreign direct investment', Economic Journal 117, F134-F161. https://doi.org/10.1111/j.14680297.2007.02018.x

Gumede, V., 2000, Growth and exporting of small and medium enterprises in South Africa, some thoughts on policy and scope for further research, Trade and Industrial Policy Strategies, Johannesburg, South Africa.

Helpman, E., Melitz, M. \& Yeaple, S., 2004, 'Export versus FDI with heterogeneous firms', American Economic Review 94, 300-316. https://doi.org/10.1257/00028 2804322970814

Hilmersson, M., 2014, 'Small and medium-sized enterprise internationalisation strategy and performance in times of market turbulence', International Small Business Journal 32(4), 386-400. https://doi.org/10.1177/0266242613497744
Homburg, C. \& Pflesser, C., 2003, 'A multiple-layer model of market-orientated organizational culture: Measurement issues and performance outcomes', Journal of Marketing Research 37, 449-462. https://doi.org/10.1509/jmkr.37.4.449. 18786

Hooley, G.J., Greenley, G., Cadogan, J. \& Fahy, J., 2005, 'The performance impact of marketing resources', Journal of Business Research 58(1), 18-27. https://doi.org/ 10.1016/S0148-2963(03)00109-7

Hove, P., Sibanda, K. \& Pooe, D., 2014, 'The impact of Islamic banking on entrepreneurial motivation, firm competitiveness and performance in South African small and medium enterprises', Mediterranean Journal of Social Sciences 5(15), 165. https://doi.org/10.5901/mjss.2014.v5n15p165

Irene, B.N.O., 2017, 'The macroeconomic landscape of post-apartheid South Africa: A critical review of the effect of the Broad-Based Black Economic Empowerment (BBBEE) Program on the success of female SMEs operators', Journal of Educational and Social Research 7(1), 145-150. https://doi.org/10.5901/ jesr.2017.v7n1p145

Kapoor, K., Mugwara D. \& Chidavaenzi, I., 1997, Empowering small enterprises in Zimbabwe, World Bank Discussion Paper No. 379, World Bank, Washington, DC.

Karedza, G. \& Govender, K.K., 2017, 'Enhancing the export performance of the SMEs in the manufacturing sector in Zimbabwe', Academy of Marketing Studies Journal 21(2), 1-19.

Karedza, G., Sikwila, M.N., Mpofu, T. \& Makurumidze, S., 2014, 'An analysis of the obstacles to the success of SMEs in Chinhoyi, Zimbabwe', European Journal of Business and Management 6(6), 38-42.

Katsikeas, E. \& Skarmeas, D., 2003, 'Organizational and managerial drivers of effective export sales organizations', European Journal Marketing 37(11/12), 1723-1745. https://doi.org/10.1108/03090560310495438

Lejárraga, I., Rizzo, H.L., Oberhofer, H., Stone, S. \& Shepherd, B., 2014, 'Small and medium-sized enterprises in global markets: A differential approach for services?', in OECD Trade Policy Papers, No. 165, OECD Publishing. https://doi.org/10.1787/ 5jz17jtfkmzt-en

Lopez, N.V., 2007, 'Export barriers and strategic grouping', Journal of Global Marketing 2, 17-29. https://doi.org/10.1300/J042v20n02_03

Love, J.H. \& Roper, S., 2015, 'SME innovation, exporting and growth: A review of existing evidence', International Small Business Journal 33(1), 28-48. https://doi. org/10.1177/0266242614550190

Manova, K., 2006, Credit constraints, heterogeneous firms and international trade, Mimeo Harvard University, Cambridge, MA.

Melville, N., Kraemer, K. \& Gurbaxani, V., 2004, 'Information technology and organizational performance: An integrative model of IT business value', MIS Quarterly 28(2), 283-322. https://doi.org/10.2307/25148636

Milanzi, M.A., 2012, 'The impact of barriers on export behaviour of a developing country firms: Evidence from Tanzania', International Journal of Business Management 7(3), 10-21. https://doi.org/10.5539/ijbm.v7n3p10

Moini, A., 2007, 'Export behaviour of small firms: The impact of managerial attitudes', The International Executive 33(2), 14-20. https://doi.org/10.1002/tie.5060330204

Mpofu, R.T. 1998, Competitiveness factors of small to medium sized enterprises in Zimbabwe: The pre and post Economic Structural Adjustment Programme era Department of Business Management University of South Africa, Pretoria, South Africa.

Mudavanhu, V., Mubata, T. \& Mudavanhu, A., 2014, 'The impact of entrepreneurship training programme on economic development in Zimbabwe: A case of Gweru', International Journal of Social Sciences and Entrepreneurship 1(9), 576-587.

Mupemhi, S., 2013, Factors affecting the internationalization of manufacturing SMEs in Zimbabwe. Investment climate and business environment, ICBE-RF Research Report N0. 62/13, viewed 15 March 2018, from http://www.trustafrica.org/en/ publications-trust/icbe-research-reports? download=378:factors-affecting-thepublications-trust/icbe-research-reports?download=378

Muponda, G., 2012, Nurturing latent entrepreneurship and the growth of small firms in Zimbabwe A case study of Harare Metropolitan Province, Department of Business Studies, Faculty of Commerce, University of Zimbabwe, Harare.

Muvingi, J., 2011, 'An assessment of Zimbabwean Merchant Banks conformity to international best practices in risk management', in 2011 3rd International Conference on Information and Financial Engineering IPEDR, vol. 12, August 19-21, 2011, IACSIT Press, Singapore.

Naude, M.J. \& Chiweshe, N., 2017, 'A proposed operational risk management framework for small and medium enterprises', South African Journal of Economic and Management Sciences 20(1), 1-10. https://doi.org/10.4102/sajems. v20i1.1621

Nunnally, J.C. \& Bernstein, I., 1994, Psychometric theory, 3rd edn., McGraw-Hill, New York.

OECD, 2009, Top barriers and drivers to SME internationalization, Report by OECD Working Party on SMEs and Entrepreneurship, OECD Publishing, viewed 01 March 2018, from https://strathprints.strath.ac.uk/15845/.

Oricchio, G., Lugaresi, S., Crovetto, A. \& Fontana, S., 2017. 'Banking crisis and SME credit risk assessment', in G. Oricchio, A. Crovetto, S. Lugaresi \& S. Fontana (eds.) SME funding, pp. 1-6, Palgrave Macmillan, London, UK.

Padachi, K., Howorth, C. \& Narasimhan, M.S., 2012, 'Working capital financing preferences: The case of Mauritian manufacturing small and medium-sized enterprises (SMEs)', Asian Academy of Management Journal of Accounting and Finance 8(1), 125-157.

Pinho, C.J. \& Martins, L., 2010, 'Exporting barriers: Insights from Portuguese smalland medium- sized exporters and non-exporters', Journal of Internationa Entrepreneurship 8(3), 254-272. https://doi.org/10.1007/s10843-010-0046-x 
Riding, A., Orser, B.J., Spence, M. \& Belanger, B., 2010, 'Financing new venture exporters', Small Business Economics 38, 147-163. https://doi.org/10.1007/ s11187-009-9259-6

Ruiz-Fuensanta, M.J., 2010, 'A predictive model of the export behaviour of small and medium sized firms: An application to the case of Castilla-La Mancha', Cuadernos de Gestión 11(2), 89-110.

Sanderson, A., 2014, 'Challenges of financing small to medium enterprises', viewed 10 March 2017, from http://www.herald.co.zw/challenges of financing-small-tomedium-enterprises.

Small Enterprise Development Corporation (SEDCO), 2011, Annual report Entrepreneurship, 8(2010), viewed n.d., from www.sedco.co.zW

Spicer, M., 2010, Exporting is good for Britain but exporters need access to finance to manage costs, British Chambers of Commerce, London.

Stokes, D. \& Wilson, N., 2006, Small business management and entrepreneurship, 5th edn., DP Publications Ltd: South-Western Cengage Learning, Hampshire.

Stouraitis, V., Harun, M.H.M. \& Kyritsis, M., 2017, 'Motivators of SME initial export choice and the European Union regional effect in manufacturing', International Journal of Entrepreneurial Behavior \& Research 23(1), 35-55. https://doi.org/ 10.1108/IJEBR-05-2015-0120

Tambunan, T., 2011, 'SME development, economic growth, and government intervention in a developing country: The Indonesian story', Journal of International Entrepreneurship 6(4), 147-167. https://doi.org/10.1007/s10843-008-0025-7

Tenenhaus, M., Amato, S., and Esposito Vinzi, V. 2004, A global goodness-of-fit index for PLS structural equation modeling, Proceedings of the XLII SIS Scientific Meeting, Vol. Contributed Papers, CLEUP, Padova, pp. 739-742.

Tinarwo, R., 2016, 'An investigation into the challenges faced by small to medium enterprises in Zimbabwe: A case of Gazaland Market', Journal of Business and Management 18(9), 148-153. https://doi.org/10.9790/487X-180902148153

Tornell, A. \& Westermann, F., 2003, Credit market imperfections in middle income 25 countries, Working Papers 9737, National Bureau of Economic Research, Cambridge, MA.
Ughetto, E., 2008, 'Does internal finance matter for R\&D? New evidence from a panel of Italian firms', Cambridge Journal of Economics 32(6), 907-925. https://doi. org/10.1093/cje/ben015

Vanacker, T., Collewaert, V. \& Zahra, S.A., 2016, 'Slack resources, firm performance, and the institutional context: Evidence from privately held European firms', Strategic Management Journal 38(6), 1305-1326. https://doi.org/10.1002/smj.2583

Van Biesebroeck, J., 2005, 'Exporting raises productivity in sub-Saharan African manufacturing firms', Journal of International Economics 67(2), 373-391. https:// doi.org/10.1016/j.jinteco.2004.12.002

Van Eeden, S., Viviers, S. \& Venter, D., 2001, 'Identifying small business problems in the South African context for proactive entrepreneurial education', in Proceeding of the 11th Global IntEnt-Conference, Kruger National Park, South Africa, 7/2001, July 02-04.

Wagner, J., 2007, 'Exports and productivity: A survey of the evidence from firm-leve data', The World Economy 30, 60-82. https://doi.org/10.1111/j.1467-9701.2007. $00872 x$

Wakelin, K., 1998, 'Innovation and export behaviour at the firm level', Research Policy 26, 829-841. https://doi.org/10.1016/S0048-7333(97)00051-6

Wetzels, M., Odekerken-Schroder, G. \& Van Oppen, C., 2009, 'Using PLS path modelling for assessing hierarchical construct models: Guidelines and empirical illustration Management Information Systems Quarterly 33(1), 177-195. https://doi.org/ $10.2307 / 20650284$

Wong, H. \& Merrilees, B., 2007, 'Multiple roles for branding in international marketing', International Marketing Review 24(4), 384-408. https://doi. org/10.1108/02651330710760982

World Bank Ghana Office, 2013, 'Access to finance for small and medium enterprises in Africa', viewed 15 February 2018, from http://acetforafrica.org/acet/wp-content/ uploads/publications/2016/03/Access-to-Finance-for-SMEs-Paper.pdf

Zindiye, S., 2008, 'An empirical investigation into the factors affecting the performance of small and medium enterprises in the manufacturing sector of Harare, Zimbabwe', Unpublished Master's thesis, University of Fort Hare, Alice, South Africa. 